\title{
Crossroads between Islamic Spirituality and the Instruction of Science
}

\author{
*SALAH MACHOUCHE ${ }^{1}$ \\ BENAOUDA BENSAID ${ }^{2}$ \\ ZURAIDA AHMED ${ }^{3}$ \\ ${ }^{1}$ Kulliyyah of Islamic Revealed Knowledge and Human Sciences, International Islamic University \\ Malaysia, 53100 Kuala Lumpur, Malaysia \\ ${ }^{2}$ Istanbul Sabahattin Zaim University, Halkalı Caddesi, 34303 Istanbul, Turkey \\ ${ }^{3}$ Kulliyyah of Engineering, International Islamic University Malaysia, \\ 53100 Kuala Lumpur, Malaysia \\ *Corresponding author: bentahar@iium.edu.my
}

Published online: 15 August 2019

To cite this article: Machouche, S., Bensaid, B. and Ahmed, Z. 2019. Crossroads between Islamic spirituality and the instruction of science. KEMANUSIAAN the Asian Journal of Humanities 26(Supp.1): 23-45. https://doi.org/10.21315/kajh2019.26.s1.2

To link to this article: https://doi.org/10.21315/kajh2019.26.s1.2

\begin{abstract}
The increased interest in understanding the influence of spirituality on the diverse domains of life, and alongside, the inherent pathways with science continues to draw the interest of both academicians and professionals. In the context of Muslim communities, however, and in view of their struggle for educational reforms, this issue is considered as highly critical, given Muslim active spiritual and religious take on life. This preliminary study explores the linkages associating Muslim spirituality to science and its instruction. This research shows that for science instruction, spirituality is naturally interconnected with science, helps broaden the horizon of exploration, nurtures Muslims' connection with the divine, and helps refine their ethical responsibility towards society and nature. Further empirical research on the effects of spirituality on students' learning attitudes to sciences and instructors' delivery would bring to light how Muslim spiritual values shape current personal and educational developments.
\end{abstract}

Keywords and phrases: Muslim spirituality, Islamic science, Islamic education, scientific instruction, Islamic pedagogy

\section{Introduction}

Science continues to accomplish great advancements in nature, technology and the overall improvement of the quality of life. However, with these revolutionary and innovative technological advancements, science appears to have failed to help 
man regain his lost balance, happiness, and peace in face of the complex moral and ethical dilemmas, escalating environmental crises, and deepening confusion on the purpose of life, morality, destiny of human societies and consciousness of the universe. This state of affairs calls for critical re-evaluation of the philosophy of science, scientific education and instructional pedagogy; the relationship between science and belief, and the potential role spirituality can play in the process of tapping inner human capabilities in the understanding of universe. It was to these conditions that Barbour referred to when he noted that the prevailing views that support the hypothesis of independence or conflict between religion and science that characterised Western narratives were in need of reconceptualisation, particularly in view of the complex dilemmas and challenges presented by the contemporary era, with respect to the advancements of secular sciences (Barbour 2000, 21).

This context of discussion first raises the need to revisit the concept of science, which, as Sardar concluded, is becoming for some "a contested territory" (2006, 164). Science is built upon the empirical method, which is based on observations, reasoning and the continual testing of hypotheses against the material world (Watson 2009, 315). However, the philosophy and methodology of science continues to be debated, especially with regards to whether science is a body of knowledge, a collection of techniques, social and intellectual processes, way of knowing, or strictly defined method (Gregory 1999, ix). Therefore, deciding on an all-inclusive definition is not possible, even for its practitioners (Sardar 2006, 161-178), especially considering that the body of "science" is not made up of a single material or element, rather, of many additional significant non-objective constituents. For instance, Thomas S. Kuhn opines that science is nothing more than problem solving within a paradigm: a set of dogmas, beliefs and values (Kuhn 1996). This implies that the very perspective from which science evolves is as critical as its very content, process and contribution.

Under the pretext of neutrality, universalism and objectivity, textbooks of secularbased science are designed with the fundamental assumption that the subject of science is independent from belief in the Creator and from the moral-spiritual implications of belief, which influence emotions, rationalising and action. Modern science has categorically reduced those fields into smaller components, or as Bakar described, "in conformity of its scientific conception of nature and its reductionist and materialist worldview, modern sciences ignores, belittles or denies altogether the metaphysical, spiritual, quantitative, and aesthetical aspects of nature" (2008, 63). Likewise, secular education seeks to fulfil material learning objectives to better serve ideologies like nationalism, and often seeks to divorce the inclination of belief, religiosity and spirituality from the business of life, education, economy, politics, arts and other domains of knowledge. ${ }^{1}$ The ideology of secularism 
according to Al-Attas is a materialistic policy, alien to Islam and Muslim societies (1993, 25), a colonialist heritage forcefully imposed on vital sectors of Muslim's life such as law and education (Esposito 2009, 84), and is construed based on the working plan of marginalising and minimising religion in the public life. Harvey Cox, Harvard University theologian, describes it as follows:

It is the loosing of the world from religious and quasi-religious understandings of itself, the dispelling of all closed world-views, the breaking of all supernatural myths and sacred symbols. It represents what another observer has called the 'defatalization of history,' the discovery by man that he has been left with the world on his hands, that he can no longer blame fortune or the furies for what he does with it. Secularization is man turning his attention away from worlds beyond and toward this world and this time. (Cox 2013, 2)

The human mind, susceptible to a narrowed perception of nature and of the Creator, is liable through his philosophy and knowledge to reduce His existence to a purely material entity with no significant value. The secular philosophy of knowledge, which affects the concept of science and the scientific teaching methodology, alters these critical conceptualisations of worldview and destiny of science, man's interests, life values and ethics, limitations and ideologies. As sign of the Creator, nature is designed with various types of knowledge ranging from mathematics, physics, metaphysics, spirituality, aesthetics and so forth (Bakar 2008, 63). Secular instruction narrows this relationship between a délivreur d'information and students' future material needs within a pragmatic mode of thinking that does not take into account the vast inter-connected nature of knowledge consisting of innate constituents, emotions, perceptions, worldviews and imagination (Moore 2005, 9).

The failure - or rather the cultural and religious inadaptability - of the secular paradigm of development in the Muslim world is visible in all aspects of life (Hassan 2010, 191-194), as shown for instance in the on-going discussion for the need to re-integrate the holistic perspective of education, which insists that teaching sciences as value-free information is not all that people need today (Miller et al. 2005). It is within this context of discussion that one appreciates that in the context of Islamic learning, students need not be disconnected from their spiritual experience or overwhelmed with material promises characterised by desire of increased control, domination, conquest, mastery, possession and quantification. The fields of science should rather be freed to allow for searching for higher achievements other than those finite and limited material and worldly ends, and to acknowledge the glory and magnificence of the Creator through grasping His signs in the universe through science. Research suggests that students are more likely 
to be active learners if instructors encourage them to think about ideas aligned to more practical goals and relate those ideas to their both innate and real life. This emphasises the necessity of making efforts to create a balance between intrinsic and extrinsic motivators in students.

For Muslims, the instruction of sciences was historically carried out in accordance to the belief in the One God, ethics and experimentation. As the primary source of Muslim beliefs and morals, the Qur'an calls for reflection, observation, exploration, questioning, reasoning, critical thinking, rationalisation and verification. At its peak, science becomes one of the many common methods used to understand the world and acknowledge the wisdom and greatness of the God and the miracles of creation. The merging of science with revelation helped Muslims shape their learning philosophy and style of generating scientific knowledge and produced a holistic approach to scientific knowledge.

Wright noted that the role of spirituality in a scientific classroom should not be construed as occupying the space or alternating "scientific knowledge" itself; rather it should align with it and increase its value by way of relating it with the meaning of human life. Spirituality in this sense is an ability which helps understand the elusive and intangible nature of the subject (Wright 2000, 8). This would require undergoing systematic changes to revitalise and nurture the effectual position of spirituality in the instruction of natural sciences, beginning with a re-definition of knowledge ( ${ }^{~} \mathrm{ilm}$ ) and science in such a way to accommodate the neglect of various other sources and forms of knowledge, as Jurjāni described it to be "the arrival of the soul to the meaning of something" $(2004,130)$. This approach to the philosophy and methodology of knowledge is not unusual. Marian de Souza recommends giving "non-scientific" knowledge a chance in the development of social wellbeing, and the integration between the empirical, mental and contemplative domains of observation. This contemplative domain provides an integrating factor because it is capable of transcending the first two by providing access to something beyond the physical realm (de Souza 2008, 31).

Islam views knowledge as one unified body with a hierarchical order. Those interconnections between the laws of nature, life and the universe are also relevant to this context, especially in view of the fact that Islam connects all of the laws of life, nature and cosmos to the Creator. Divine names like the Al-Rabb (The Lord), Al-Khaliq (The Creator), Al-Malik (The Sovereign), Al-Hafiz (The Protector), Al-Musawwir (The Maker), Al-Qayuum (The Sustainer), Al-Bari (The Originator), Al-Alim (The All-Knower) and Al-Qawiyy (The Powerful), all support this basic theological principle. Bakar $(2008,71)$ observed that: 
There has never been any cleavage between the laws of nature and the laws of God. The laws of nature too are divine laws. All laws are reflections of the divine principle. God is the Laws-Giver. He manifests His Will both in cosmos and the human domain through laws.

Islam also sees the science of nature as a gate of faith and fundamental step in the reading of the divine open book. According to the Qur'an, the creation of the heaven and earth is much greater than that of humankind (Qur'an 40:57). Similarly, the Qur'an approaches the future of the physical world spiritually and describes it a fertile ground of inculcating piety, tranquillity, serenity, appreciation, gratitude and humility. Concepts like mīzān (balance), taskhīr (malleability-survivability), ajal (term), sunan (law and order), taqdīr (measurement), taswiya (perfection) and taswir (fashioning) are being used as stimuli for spiritual meditation and reflection.

Drawing back on the concept of knowledge ( $\mathrm{ilm}$ ) however, one notices that the linguistic examination of the root word 'ilm and its semantic field in the Qur'an shows that the term accommodates a wide range of perceptions, cognitive activities and domains of knowing (Rosenthal 2007, 19). It denotes all that which belongs to God: the Angels possess, the Prophets received or humans acquire. It also accommodates all forms of knowledge: intuitive, emotional, rational, experiential or perceptional. The Qur'an describes knowledge as enfolding of three information (data), inner state and outer act. Knowledge also embraces different key descriptions such as the process of knowing and identification with the knower and the known, cognition (ma' 'rifah), process of attaining ( $h u s \bar{u} l$ 'idräk) or search through perception, form/image (surah), concept or meaning (ma'nā), belief, ability of remembrance, power of imagination, vision, opinion, motion of the heart, negation of ignorance and result of intuition coming from outside or as a result of introspection (Rosenthal 2007, 52-68).

The reference to the divine as a spiritual anchor for knowledge and science merits attention as it is found to be more influential than the very human agency or the conditions surrounding the processes of knowledge production. This finds illustration in the Qur'anic account of the creation of man. According to the Qur'an, God taught Adam the names of all things (Qur'an 2:31). Those names, posited Rāzi (d. 925), refer to the attributes, descriptions and qualities of things (Rāzi 1981, 194). For him, this verse highlights the significant position of knowledge in Islam, and further informs of the reader that knowledge was the medium through which God demonstrated His glory, especially when He challenged the Angels to name things and beings. The preordained relationship associating religion and science are also shown in the first divine command, 'iqra' (read), which invokes several modes of learning and knowing including tafaqquh (understanding), tabligh 
(conveying), tamhịss (verifying), jam ' fi al-qalb (memorising), dirasah (study) and istiqra ' ' (inducing) (Lane 1968, 2502-2504). Along similar veins of thought, Unal proposed the exploration of nature as a study of a book with interrelated and inter-connected chapters, paragraphs, sentences, words and letters - a study with procedures peculiar to itself, such as observation and experimentation (Unal 2010, 1182). Reading 'iqra,' in the Islamic understanding, is then a highly engaging intellectual exercise leading the reader to know and connect with the divine.

The above discussion highlights the need to re-consider the Islamic insight on belief and spirituality in the process of restructuring and broadening the extent and horizon of scientific instruction for Muslim audiences. Such inclusion would hopefully help learners recognise and acknowledge the relevance, meaningfulness and significance of other sources of knowledge. Furthermore, it will help students connect their spiritual experience with the content of science, use their innate abilities to further understand natures or appreciate the laws of the physical world, and learn how to grasp the meanings of things; how are they inter-related; and who and why in the first place related them.

\section{Concept of Muslim Spirituality}

The meaning of spirituality remains notoriously difficult to define with many opinions (Wright 2000,7). Swinton sees it as "a personal and social process that refers to the ideas, concepts, attitudes and behaviours that derive from a person's, or a community's interpretation of their experiences of the spirit" $(2001,20)$. Elkins et al. (1988) define it as "a way of being and experiencing that comes through awareness of a transcendental dimension and that is characterized by certain identifiable values in regard to self, others, nature, life and whatever one considers to be ultimate". For some others, spirituality in the field of learning and education is concerned with the realm of human life that is non-judgmental and integrated, and is about belonging, connectedness, meaning and purpose (Lantieri 2001). With its major divisions in matters of religiosity however, spirituality is claimed not to be a part of conventional religious belief.

Yet, in spite of the fundamental differences surrounding the definition, role and position of spirituality in science and society, many researchers appreciate its relevance and significance in the broad areas of knowledge in general. In the field of health sciences for instance, nursing accommodates spirituality aid for the treatment of patients and their healthy recovery (Speck 2007, 16). A growing scholarship is advocating for spirituality to be recognised as an independent and well-defined science in areas of health care, nursing, business and management, and is increasingly seen as such (Giacalone and Jurkiewicz 2003). With respect 
to the field of education, some define its main purpose as the development of the whole person and the respect all of needs of a human's innate nature (fitrah) including the spiritual, emotional, intellectual, physical, social and aesthetic (Baba and Zayed 2015, 52).

In Islam, however, spirituality has special character. The Qur'an makes reference to human nature using two words interchangeably: rūh (soul, breath, spirit) which appears on 21 occasions, and nafs (self) on more than 260 times. According to the Qur'an, humans do not have access to the domain of rūh and only have limited knowledge of it (Qur'an 17:85). In such context, spirituality may be defined as the very religion that regulates the relationship man and his Creator, himself, fellow humans and with the surrounding environment. According to Nasr (2006), the term ruhaniyyah is the prevalent translation for spirituality; the term deriving from $a l-r \bar{u} h$, meaning spiritus. Nasr defined spirituality as the inner spiritual dimension of traditional religions dealing with the noumenal and which can only be experienced directly, and which extends beyond mental categories, but is not antiintellectual $(2006,209)$. This view finds support in Muslim spiritual tradition, which presupposes that neglect of the soul results in corruption of the inner being, and its eventual decline (Qur'an 91:9-10). For Nasr (2006), Muslim spirituality is reflected in the presence of a relationship with Allah, affecting individual selfworth, a sense of meaning, and connectedness with others and nature.

Spirituality may also be described as the state of heart (mind) and as a relationship with God, His signs, and with both animate and inanimate creatures. Spirituality denotes the human experience, whose essence and form are construed according to their obedience and submission to the divine, by way of certain beliefs, worship (rituals), social relations and knowledge of the world. Spirituality capitalises on one's inner purification; this involves observing the inner states of the self, known notoriously as the acts of the heart, and necessitates nourishing and preserving good manners and states of the heart ( $h u s n$ al-ahwa all), exercising specific disciplines leading to the embodiment of virtuous habits (riyädah mahmüdah), in addition to other additional requirements. Likewise, Islamic spirituality is not a subjectively self-centred experience that cannot be captured; it is rather a self-experience built on well-defined foundations and clear theoretical frame provided by the teachings of Islam. Spirituality may escape the parameters of broad generalisations and quantifying measurement emphasised in the conventional scientific methodology, there are however, other alternatives allowing for the objective explanation, expression and transmission of its experience.

The composition of Islamic spirituality of belief, rituals, behaviour, knowledge of the world and subjective experiences causes its relevance to science and its 
instruction not an impossible task. The measures which may be taken in the very beginning to make this integration process successful and indispensable to science is considering the field of instructed subject. The instructors should pay due attention to the connections established between spirituality and science with different learning contexts. With the multitude of science subjects, those interconnections would vary from field to another and from subject to another. Moving towards that direction, Islamic spirituality is set to inculcate God's presence through appreciating the universe as a sign of divine creation, or as Syed Sajjad Husain noted: "it must be such that faith is infused into the whole of his personality, creating in him an emotional attachment to Islam which enables him to follow the Qur' an and the Sunnah and be governed by the Islamic system of values" (Husain and Ashraf 1979, 74).

Having said that, Muslim spirituality is not restricted to the fold of rituals and worship, nor is it contained in specific religious services. This is because worship is broad and allows for diverse contributions allowing one to address spirituality through natural sciences and vice versa. Pre-modern scientific discovery often joined between the organic unity of science and spiritual knowledge (Bakar 2008, 61). Similarly, the review of spiritually driven science content in the field of education and instruction should not be viewed as a disguised escape or diverted from empirical objectivity, or a course causing disinterest in the study of the universe or exploitation of natural resources. On the contrary, the active presence of spirituality in the instruction of science assumes a profound position and role, further strengthening the spiritual credibility, validity, rational harmony and contribution to shaping meaningful and constructive explanations and solutions. The questions and answers of spirituality, which are a complex interaction of beliefs, worldview, concept of life, values, tastes and actions, are expected to generate active engagement and a strong motivation and commitment to understand nature and solve it mysteries, grasp the signs of the divine in the world, appreciate the divine blessing and bounties, and accordingly use and manage environmental resources wisely and responsibly.

\section{The Crossroads between Science and Spirituality}

In the following section, we will briefly highlight some of the basic theological premises underlying the incorporation spirituality into learning and education, specifically the instruction of sciences. These premises do not fully illustrate the theological spectrum in its complexity surrounding the topic but instead seeks to provide the reader with the necessary understanding of issues like the worldview of tawhid, divine order and providence, human accountability and responsibility. The effects of worldviews are far-reaching, influencing personal 
beliefs and attitudes, community organisation and life, and furthermore effects a multitude of other dimensions of behaviour. Worldviews also explain, support and validate many scientific claims, especially those falling outside the boundaries of experimentation, and illustrate fundamental concepts like universal consciousness. A relevant example is the presupposition many scientists make with regards to "the physical world exists and is substantially comprehensible to us" (Gauch Jr. 2009, 35). The conventional methods of "science" on their own cannot prove such a fundamental statement; they would require the supporting worldview originating from religion, natural philosophy, natural theology and other sources.

Tawhid however, bridges spirit with matter, instils values, gives life meaning and value, especially with respect to fundamental questions of existence. It helps re-evaluate human coping with problems and crises, and sustains and guides the processing of knowledge production, protection, purification and application. For Islam, knowledge and learning need to be fundamentally built and developed on the basis of belief, and shaped according to faith, spirituality, morality and ethics. It is according to this worldview that one appreciates the need to allocate space in defining the fundamental concepts of science; and more specifically, to draw upon the principle of tawhid in introducing spirituality to sciences in classrooms. The reference to worldview in the setting of a scientific classroom is set to help re-wire students' spiritual inner background with fundamental frameworks of thinking and to further allow them to critique the conventional concepts, assumptions, values, methods and reality of science. In such a context of learning science, the engaged discussion between instructors and students is not trapped in the dead matter of the superficial nature, but rather given a chance of drawing on the transcendental premises of creation, life and ethical values. It is through this perspective, that learning would reduce the binary limitations of modern science while encouraging new inter-disciplinary domains of creativity, epistemological debates, and distinct outlook towards developing sciences and shaping their theoretical and ethical orientations. As early as the 9th century, the Arab-Muslim physician, Rahawī, the author of 'Adab al-Tabīb (medical ethics) said the following:

The first principle the physician must consider is honesty and trust. The source of honesty comes from the belief that every existing being (mukawwan) has a Creator (mukawwinan), the One, the Powerful, the Wise, the Willing; Who causes everything to be intentional. The One Who gives life, causes death and sickness, and grants healing. $(1992,26)$

Divine Order and Providence are also worth attention in the context of spirituality and science. One finds that in its description of nature, the Qur'an uses terms like khalq-Allah (the creation of God) (Qur'an 31:11), sun 'u Allah (the artistry of God) (Qur'an 27:88) and 'alam (world) which is derived from 'alamah meaning 
sign (Tahānawi 1996, 1157). The word "nature" translates in Arabic into tabi" ah. This is not used in the Qur'an, however, its verbal forms of taba ' $a$ and yatba ' $u$ are used to mean veiling or sealing and are also used exclusively with the word qalb (heart) to mean sealing up the heart; this carries little implications with the later definition of tabi ${ }^{-} a h$ (Solihu 2014, 245). Nature is approached as sign rather than a material object or force to be opposed and conquered (Chopra and Mlodinow 2011, 11). For early Muslim scholars, the world (al-'alam) denotes every created thing (except God) whether in form of essence or accident. They use the term to mean "something which makes the Maker known" (Tahānawī 1996, 1157). The Creators' signs in the universe (ayah) work as "pointers to the providential purpose at all levels of creation" (Kamali 2006, 142). The Qur'an also treats the entire created cosmic order and all of its constituents as signs (ayat). Signs point to something other than themselves, and hence, the cosmos and all which it contains are signs of a unique Creator who created the signs through a simple command of "Be" (Qur'an 36:82) (Iqbal 2009, 34).

The Qur'anic approach to nature, however, is shown throughout a two-directional law of cause and effect: one horizontal, involving objects and another vertical (objects + signs $\rightarrow$ Creator will). Nature is governed through a "purposiveness" that is defined by divine wisdom, avoiding happenstance, chaos or coincidence. The Qur'an describes those natural measurements with words like (miqdār, taqdīr), balance (mizān), perfection (itqān), malleability, amenability, order and set of laws of creation (sunnat-Allah/khalq-Allah, sun'-Allah). The Qur'an is replete with references to the constant divine intervention in nature as shown in the description of rain, winds, thunder and growth of vegetation. The Qur'an contains about 64 verbs that describe nature, and in some cases, uses questioning styles to draw human attention to those relationships (Qur' an 56:64; 56:68-69).

Iqbal noted that the natural world with its pre-fixed laws and rules is perishable; those sets of laws and rules are exclusive to our existence (Iqbal 2009, 34). According to tawhid, the laws pertaining to the balance of nature and permanence of the world are not self-subsistent, rather they are governed by the Creator who causes them to function and continue functioning. According to the Qur'an, God's commands are not separate from the function of these laws (Qur'an 30:25) nor are the laws (sunan) independent from the divine Will. As al-Farūqi noted, the work of the divine dictates the following:

God is the First Cause of everything, and that none else is. God's power is not so remote, and His Causation is so indirect as to render Him as deus otiosus, a "retired" God. Muslim philosophers do not assume that God's causality can be assigned to the creation, nor that the cosmos can 
function as a wound-up mechanical clock with no need for its clock maker to operate. (1986, 51-52).

Third, we touch upon human responsibility and accountability. Islam encourages its followers to make use of Earth's available resources with wisdom and moral values. The Qur'an describes the position of Adam as khaliffah (vicegerent) which invokes meanings of status, succession, inheritance, replacement and responsibility. The Qur'an also uses other related terms such as reform (isläh), settlement or establishment (tamkinn) and the making of human association ('umrān) to describe the principles of stewardship and responsibility. Similarly, Islam reminds man of his responsibilities, with the Qur'an associating responsibility with the proper use of faculties, cognition and senses (Qur'an 17:36). Having been created with a freewill, humans are held responsible for the corruption on earth (Qur'an 30:41). Islam cautions man from all sorts of evil and corruption, including fasād (spoiling), isra $\bar{f}$ (excessiveness), tabdhīr (waste), tughyan (oppression), ta 'adī (transgression), taghyīr khalq Allah (bring destructive change to Allah's creation), zulm (injustice), greed and selfishness. Islam sets these human responsibilities and obligations within a framework of shari 'ah fundamental tenets which dictates preservation and promotion of human life, that is, religion, life, dignity, intellectuality, property and environment (Ibn Ashur 2006). Likewise, Muslim scholars have shown a great interest in the study of responsibility and accountability. Independent institutions known as hisbah (inspection) were set accordingly to evaluate professional practices and environmental friendliness as with the case of engineering and the hydro-powered clocks and machines designed by al-Jazarī (d. 1206).

The inter-connectedness of spirituality with science is further manifested in how Muslims are impressed with varying spiritual principles when instructed in science, and how certain model of spiritual-science intimacy comes into effect whereby both domains naturally converge to supply the chemistry needed for particularly defined character of life, science and ethics. Some of those modes according to which spirituality connects to the study and teaching of science, include the role of spirituality as a motivation to science, as a guide to the divine truth, and spirituality as moral compass.

While science is concerned with the observable occurrences in nature, spirituality is rather concerned with purpose and perceptions of these natural events how they connect scientists with the divine. With its transcendental view of the world, spirituality seeks to fill up the gaps of understanding with meaning and purposiveness. Spirituality should neither be dismissed altogether, especially with regards to the active presence of intuition and subjective feelings nor taken as escape from the objective work of science; but rather should operate within the 
context of scientific investigation, challenged with fundamental questions, and having a capacity which supersedes the conventional horizons of science; including for instance questions of universal consciousness, life purpose, origins of the world and human destiny. In this context, one appreciates the Qur'anic account of Prophet Abraham's search for the truth, his big questions, and imploring to God to show him how He restores life. Abraham said: "My Lord, show me how You will restore life to the dead!" God said: "Why? Do you not believe?" Abraham said: "Yes, but that my heart may be at rest" (Qur'an 2:260) (Unal 2010).

Aside from his deep-seated curiosity, Abraham was strongly driven by spiritual longing for the tranquillity of the heart ("My heart may be set fully at rest"). His request "show me" was used as fundamental scientific tools of verification and understanding. This partly explains how the "showing of science" is expected to pave the way for spiritual experience and inner peace.

Spirituality carries with it multiple tasks including broadening the scope of investigation and array of thinking about the reality, beginning with the tangible and observable to the intangible and unseen reality. Although scientific theories provide a rich area of experimentation and intellectual construction, empirical verification yet does not capture many other elements. Spirituality however, helps sustain harmony of thoughts while nurturing confidence and the tranquillity of mind necessary to the construction of sustainable scientific knowledge. A disrupted spiritual state may lead to absolute scepticism followed with uncertainties, confusion, disorder and moral chaos. This connection of spirituality with science can be illustrated through the power of intrinsic motivation which drives scientists to explore, discover and benefit human society. Throughout different complex levels, the movements of the human reasoning provide this motivation slowly with increased understanding of the whole. Spirituality, however, supplies a holistic connection embracing various levels of manifestation, systems, perspectives, orders of things, to which belongs the physical world (nature).

It was with this holistic outlook that early Muslims scholars strove to explore nature not only to exploit its inherent laws and resources, but also to nurture their consciousness about the greatness of the Creator and His majestic creation, and to further cultivate their spiritual discipline. Muslim scholars have traditionally approached nature based on their perspectives of both reality and Gods signs (ayat). The first was set to understand the nature of things and their benefits for human life. The second however, sought to grasp the essence of things, their inter-relationships and order and ways of reflection upon the glory of the divine. Therefore, acquisition of the knowledge of nature, understanding its laws, is perceived as an effective avenue leading to the divine and drawing near to Him. 
Interestingly, the Qur'an refers to this power of reference to the divine found in natural phenomena. Using the evidence of the creation of the heavens and the earth, God argues against those who disbelieve saying: "Do those who disbelieve ever consider that the heavens and the earth were at first one piece, and then We parted them as separate entities; and that We have made every living thing from water? Will they still not come to believe?" (Qur'an 21:30). This verse also explains how those who see (understand) the creations of heaven and earth need not entertain disbelief and furthermore alludes to the vibrant linkages imbued in the physical world connecting humans with themselves, their community, environment, with more importantly with the Creator.

The bridging of spirituality with scientific instruction raises the following three spiritual values, which altogether affect the holistic view of spirituality with regards to emotions, reasoning and action. These values are remembrance of the divine (dhikr), contemplation (fikr) and gratefulness (shukr). Each value stimulates different parts of the learner's personality. For example, the practice of contemplation and demonstration of gratefulness helps generate awareness and self-consciousness of the divine, of His signs in the creation, his divine blessings and bounties; all of which trigger positive thoughts and reflections about the Creator and the created universe. The power of contemplation, gratefulness and mindfulness according to the Qur'an is twofold: one relates to finding and acknowledging the truth; the other in determining falsehood and eliminating it. The Qur'an sees contemplation and gratefulness as essential to those endowed with a "deep understanding" ('ūlu al-albāb). Similarly, remembrance of the divine in the context of scientific instruction should be seen as a necessary soft-skill needed for developing the positive attitude of creativity and scientific thinking. This gratitude helps believing scientists acknowledge and appreciate the blessings and bounties of God while supporting a balanced mindset, which in turn opens avenues for human potential and assists students to manage science diligently with morality and honour of life fundamental values like belief, life, intellect, fitrah, human progeny, wealth, freedom and justice.

As a form of moral sensor, guide and shaper, spirituality shapes moral consciousness and affect the moral decisions in learning of science, conducting research and instruction. Spirituality influences workplace ethics, and the redefining as well as operationalising of values such as trust, integrity, justice, respect, responsibility, care and perfection. Spirituality is also considered as "a framework of organizational values evidenced in the culture that promote employees' experience of transcendence through the work process, facilitating their sense of being connected to others in a way that provides feelings of completeness and joy" (Jurkiewicz and Giacalone 2004). Spirituality also has a special position and role 
to play in the fields which seek the alleviation of human suffering, encouraging the scientists not only to intervene with solutions and inventions but also with sympathy towards those in pain and suffering or enduring hardship. ${ }^{2}$

\section{Spirituality in the Writings of Muslims Scientists}

To satisfy the evolving perceptions and ambitions of human society, learning is generally found to be culturally construed. For Sloan, every education implies some underlying image of the human being $(2005,27)$. As far as the Islamic approach to learning is concerned, the system of belief, perceptions of human nature, human needs and the meaning of life are the fundamental to the Islamic teaching framework. This explains the effects that said perceptual differences have had on the diversity of learning systems throughout history. A major segment of the development of learning focuses on the perception of human nature and meaning of life. First, both the Muslim notion of vicegerency and devotion to the divine help learning acquire a dimension of spirituality, nurture one's intimacy with the divine, and enhance balance in both the soul and body. For Muslims, attention to the soul is paramount, as showcased in many early treatises which prioritise the needs and longings of the soul over the body in the process of learning (Bensaid and Machouche 2017, 339-350).

The literature of early Islamic education is replete with instances of instructors urging their students to take the pleasure of God and pursuit of spiritual reward as their highest and ultimate interest. According to Zarnüjī (d.1223), this is of utmost importance to learners. Zarnūjīi illustrates this point as follows:

In his request for knowledge to strive for the good will of God [Allah's pleasure], the future life [hereafter], the removal of ignorance from himself and the rest of ignorant, the conservation [revival] of religion and the survival of Islam. For the survival of Islam depends on knowledge. The ascetic life and piety are not perfect where there is ignorance. $(1947,25)$

Muslim educators often initiate their learning sessions with the reminding of students to have the proper motive and right intention of seeking the pleasure of God by quoting the authentic and famous hadith of Prophet Muhammad: "The reward of deeds depends upon the intention and every person will get the reward according to what he has intended" (Bukhari 1997, 45). Besides the transfer of knowledge and life skills, the objective of holistic learning aims to nurture the positive personality and learners' refined moral characters, with the goal of disciplining the mind and heart; acquiring good attributes of mind and soul; 
accomplishing the correct against the erroneous action, of right against wrong; and of preserving individuals from disgrace and humiliation (Al-Attas 1993, 49-50). Hussain noted that education seeks to build a balanced and holistic growth of the individual's personality through the training of the spirit, intellect, rational self, emotions and bodily senses. Islamic education caters for the growth of man in all aspects: spiritual, intellectual, imaginative, physical, scientific, linguistic, both individual and collective, and motivates all these aspects towards goodness and attainment of perfection (Husain and Ashraf 1979, 44). Additionally, it is built on core principles of nurturing (tarbiyyah), teaching ( $t a$ ' lìm), disciplining ( $t a^{\prime}$ ' $\bar{\imath} \mathrm{l} b$ ) and so forth. It capitalises on instruction ( $\mathrm{ta}$ ' $\mathrm{lim}$ ), study (ta' allum), purification (tazkiyyah), discipline (ta'dīb/tahdhīb), guidance (tarshìd/tawjīh) and fostering (tanshi'ah).

Among the many Muslim works that appear to have appropriately echoed these main objective of learning in the various fields of learning are the treatises of Adab al-Qādi (ethics of the judge), Adab al-Kātib (ethics of administrations), Adab al-Tatbīb (ethics of the physician), Adab al-Mulk (ethics of governance) and Adab al-Sāmi' (ethics of the listener) (Tahānawī 1996, 127-128). Muslim education, whether pertaining to the study of religious tradition or nature and society, shows a keen interest in the inculcation of the belief in the One God and drawing humankind nearer to Him. Science in Islamic civilisation, as Bakar puts it, was born in the cradle of religion. More precisely, it was born in the cradle of belief in the One God - what Muslims traditionally call tawhid (Bakar 2008, 113). Traditional Muslim scientists and technologists have clearly embraced this God-centric worldview, which presumes that reality is not limited to the world of sensory experience and observation (Bakar 2008, 109).

Early Muslim scientists credited spirituality in many direct and indirect pathways as shown in their passionately written prefaces on spirituality set to remind the learner about the greatness, glory and blessings of God, His Will and Perfection, purification of intent in their intellectual pursuits, human destiny, the unseen world, and the need for prayers and invocations. Throughout their technical writings, they prefer to use soft spiritual language styles and repeat spiritual statements like insha'a-Allah (God willing). In his book Kitab al-Tasrif, Zahrawi often ends his explanations with insha'a-Allah, bi-hawlillah (by the leave of God), 'Allah a 'lam' (God knows best) and so forth (Al-Zahrawi 2006). In the following, however, we select some illustrative examples of Muslim scholars to demonstrate scientists' spiritual persuasions and their deep commitment to the divine. One of those is Nawawi (d. 1277) who posited that one of the primary responsibilities of educators is to motivate students to uphold the right and pure intent, to constantly observe 
the commands of God and to uphold them in their speech, action and feelings. For him, educators should let their students appreciate how those virtuous acts open for them both their hearts with fountains of wisdom and inspirations and gates of knowledge (Nawawi 1987, 34).

Another exceptional scientist is Muhammad ibn Mūssa al-Khawārizmī (d. 850), otherwise known as the father of algebra, a polymath with many contributions to the fields of mathematics, astronomy and geography, and the history of sciences. In his master work, Al-Jabr Wal-Muqābalah (The Algebra), al-Khawārizmī clearly ascribes spirituality a high position:

Praised be God for His bounties towards those who deserve it by their virtuous acts; in performing which, as by him prescribed to His adoring creatures, we express our thanks, and render ourselves worthy of the continuance (of His mercy), and preserve ourselves from change; acknowledging His might, bending before His power, and revering His greatness. (Al-Khawārizmī 1831, 1)

In his description of the motives of writing his book, al-Khawārizmī revealed his spiritual inclinations, and related his intents to the scholars of the previous generation who worked hard in different branches of knowledge while simultaneously bearing in mind the divine reward proportionate to their contributions. Interestingly, al-Khawārizmī made reference to the following three objectives: making novel discoveries and inventions; developing simple methods to provide easier access to science and to solve problems; and lastly, to review, re-organise, correct and critique previous works without arrogance towards them, or taking pride in what they did themselves (Al-Khawārizmī 1831, 16). Al-Khawārizmī narrates how after being commissioned by the ruler Abū Ja far al-Ma'mūn (d. 833), he composed a short work on calculating by (the rules of) Completion and Reduction, introducing the simplest and most useful arithmetic tools which people urgently needed to observe their due rights and avoid the unlawful in their dealings with one another (Al-Khawārizmī 1831, 3).

Throughout the development of his algebraic functions, al-Khawārizmī was highly driven by the fulfilment of his religious duties; this is demonstrated by how algebra assists branches of Islamic jurisprudence to fulfil religio-scientific questions like the science of inheritance calculation (' $i l m$ al-furūd). In his work, he states that his main goal was to compose a short work to introduce an easy and useful arithmetic tool to better handle and manage the cases of inheritance, legacies, partitions, lawsuits, trade, the measuring of lands, the digging of canals and all manners of geometrical computations (Al-Khawārizmī 1831, 4). Again, al-Khawārizmī expressed his spiritual feelings, and supplication for success and confession of 
utmost reliance on God, saying: "My confidence [trust] rests with God, in this as in everything, and in Him I put my trust. He is the Lord of the Sublime Throne. May His blessing descend upon all Prophets and Messengers" (Al-Khawārizmī 1831, 4).

Another relevant example of the clear merging of spirituality and science is found with al-Bīrūnī Abu al-Rayhan (d. 1048). Following his education of religious and foreign sciences extending over 25 years, Bīrūnī produced works on mathematics, astronomy, geography, pharmacology, history of religions and mineralogy. His scientific thinking led him to believe that the universe has a mathematical structure (Samaian 2011, 139). Moreover, Bīrūnī chose not to follow the prevalent natural philosophical presupposition on the independence of nature from its Creator or non-existence of the transcendent God. He rejected Aristotle's dualistic physics and proposed that the entirety of the physical universe is ruled by a single set of physical laws, which is tawhid (Ahmad 1995, 399). In his preface, Bīrūn̄i implored God for the success of his work, prayed for guidance to achieve his objectives, and protection from errors (Bīrūnī 1954, 5). Interestingly, he composed a whole chapter on the calendar and religious holidays, birthdays, fixation of fasting time among different religious communities (Jews, Christians and Muslims) and the determination of the direction of Muslim prayer (qiblah).

Working on religious matters cannot be seen as an isolated interest with no connection to spirituality. These research fields in astronomy should have some meaning in the life of Bīrūnī, especially with his famous work "Canon of astronomy" (Al-Qānūn al-Mas 'üdi fil-hay'a wal-nujūm) with the question on who is the happiest person (al-mas ' $u d$ ). According to him, "the happy person is someone who is happy because of [his belief] in God, the Great and the Highest and he received His support" (Bīrūnī 1954, 1). Bīrūnī's epistemological framework includes the acknowledgment (taqabbul ijtihad man taqaddamahu bil mannai), correction ('istișwāb wa taṣhị al-khața') and improvisation. He also compared scientific statement (al-qadiyyah) and its evidence (al-burhan) with the soul and body in their relationship and stressed that obtaining certain knowledge ( 'ilm al-istiqān) requires both.

Another example of science with spiritual emphasis can be found in Taqi al-Din Abūbakr M. ibn Qādhi al-Asdi al-Rashīd (d. 1585). A Damascene astronomer who worked in Istanbul, Taqi al-Din excelled in mathematics, astronomy, engineering, mechanics and optics (Ayduz 2014, 315-317). In one of his works, entitled Al-Kawākib al-Duriyya fi wad' Bankamāt al-Dawriya) (The Shining Stars in Making Round Watches), Taqi al-Din dedicated significant attention to spirituality, beginning by reminding his reader of The Causer of motion and inertia 
and requesting him to send salutations for Prophet Muhammad. He concluded his short spiritual introduction with a supplication and quoted the tradition of the Prophet to justify the writing of his work. On more than 25 occasions, he used the statement "Allah knows the best/ the right", "praise be to God", "if Allah wills", "success is in the hands of Allah" and "I rely on Allah". He chose the mosque-like design as background of his time-machine model. ${ }^{3} \mathrm{He}$ concluded his work with the following: "Allah is the source of success and support. He suffices us and blessed is He the Trusted. Blessed in the Guardian and Supporter. No alteration no power except by the leave of Allah the Great." 4

The presence of this spiritual language tone and content carries multaipleimplications which altogether stand as evidence that thinking scientifically does not necessarily dismiss spirituality; rather that they complement each other in producing a holistic and comprehensive image for reality and the universe. The few examples we have provided so far show that the co-existence of science and spirituality do not reduce the value and credibility of science which champions the empirical evidences and facts nor of spirituality. The examples of those Muslim scientists and others like Ibn Hayyan (d. 815), Buzjānī (d. 998), Ibn Sina (d. 1071), and Khayyam (d. 1100) and Jazarī (d. 1206) only show that spirituality was a significant motivator for their works and that they have accommodated spirituality in their conduction of science. Their integration of spirituality in science was neither burdening nor impeding to their objectivity, rigour, innovation, or criticality in the study of natural phenomena, but rather amplified by their pursuit of happiness, divine reward, religious obligation, solving community problems and so forth.

\section{Conclusion}

With the favourable stand of Islam on the incorporating of spirituality into the instruction of science, the process need to undergo fine systematic adjustments and adaptation, whether with respect to content selection, formulation of scientific relevant problems and questions, or explaining the moral and ethical dimensions. This preliminary research on Muslim spirituality and science shows that attention to spirituality in the teaching of natural sciences carries with it many advantages, it revives the integrated nature of Islamic education, remedy the declining approach and delivery of current education in face of the aggressive rigidity and exclusion of secularism. For Islam, spirituality is not alien to scientific thinking, rather constructive in the Islamic pedagogy. However, the re-integration of spirituality into scientific instruction requires holistic approach and framework in both the theoretical and practical to develop appropriate pedagogical tools needed in the scientific educational context. 


\section{Acknowledgements}

This work is funded by the Research Management Center, International Islamic University Malaysia under the Research Initiative Grant Scheme (RIGS) 20172018 (RIGS 16-165-0329).

\section{Notes}

1. Along similar lines, one finds many contemporary Muslim intellectuals and scientists choosing to define science as a neutral universal entity and enterprise that transcends all cultural and religious values identified by human communities. Dallal (2010), Guessoum (2011) and Hoodbhoy (1991) for example, work hard to preserve a secular version of science, one which treats the body of knowledge independently from religion, human and social influences. Dallal for instance emphasises that all religious and scientific knowledge are assigned to their respective compartment. This, in his opinion, justifies the pursuit of science, and even the use of scientific discourse in commenting on the Qur'an while simultaneously limiting its use in scientific discourse $(2007,10)$. Guessoum, on the other hand, sought to recall a historical case for such independence, which articulates for both religion and philosophy a distinct path and position as shown in Ibn Rushd's thesis (The Decisive Treatise, Determining the Nature of the Connection between Religion and Philosophy) (d.1198). Guessoum considered the Rushdian philosophy worth adoption because he believed it established that religion and philosophy (wisdom), which can be expanded to truthful knowledge like science, cannot be contradictory; they are in fact "bosom sisters" and express the same truth in different ways (Guessoum 2011, 61). Pervez Hoodbhoy pushes this hypothesis a little further to what he describes as an irreconcilable conflict between a metaphysical system based on faith and the demands of reason and empirical enquiry (1991, 2).

2. The Qur'an speaks of Dhul-Qarnayn (the two-horned one) as being endowed with power and prestige of kingship and spiritual strength (Asad 1980, note 81). DhulQarnayn had the knowledge of material things and is reported to have erected a solid rampart to protect people. However, he refused to exploit the people's critical need of assistance in return for material profit. By mixing blocks of iron and molten copper, he built what the Qur'an describes as an impenetrable structure so as to prevent the aggressive tribes of Gog and Magog to surmount or dig their way through and cause harm to the affected people. With his outstanding engineering accomplishment, Dhul-Qarnayn acknowledges the true source of his knowledge and strength; neither showing arrogance, pride or self-glorification, but instead, maintaining humility and appreciation of God's favour's and mercy (Qur'an 18:98). He was aware of the temporary nature of the structure he erected, and as such, was able to avoid all perceptions in the absolutism of structures but rather drew attention to God's everlasting power instead (Qur'an 18:98). 
3. Taqi al-Din Ma'rūf, al-kawakib al-duriyya fi wad' bankamat al-dawriya (Manuscript: ARABE 2478, Source: gallica.bnf.fr/ bibliotheque nationale de France), pp. 80, 172.

4. Ibid., 172 .

\section{References}

Abdul Razak Mohd. Abbas. 2014. Man and nature: An Islamic perspective. Bishawar Islamicus Journal 5(2): 1-13.

Ahmad, I.A. 1995. The impact of the Qur'anic conception of astronomical phenomena on Islamic civilization. Vistas in Astronomy 39: 395-403. https://doi.org/10.1016/00836656(95)00033-x

Al-Attas, Syed M. Naquib. 1993. Islam and secularism. Kuala Lumpur: International Institute of Islamic Thought and Civilization (ISTAC).

Al-Faruqi, Isma'il Raji. 1986. Al-Tawhid: Its implications for thought and life. Virginia, USA: International Institute of Islamic Thought. https://doi.org/10.2307/j. ctvk8w28n

Al-Khawārizmī, A. Muhammed Ben Musa. 1831. Al-jabr wal-muqābalah (The algebra) (edited and translated by F. Rosen). London: The Oriental Translation Fund.

Al-Zahrawi, Abul Qasim Abbas. 2006. Kitab al-tasrifli man 'ajaza 'an al-ta'lif. Damascus: Manshurat al-Hay'ah al-'Amah al-Suriya il-Kitab.

Asad, M. 1980. The message of the Qur'an. Gibraltar: Dar al-Andalus.

Atighetchi, D. 2007. Islamic bioethics: Problems and perspectives. Dordrecht: Springer.

Ayduz, S. 2014. Taqi al-Din Ibn Ma'ruf: A bio-bibliographical essay. In The Oxford encyclopaedia of philosophy, science, and technology in Islam, 315-317. Oxford, US: Oxford University Press.

Az-Zarnuji, Burhan al-Din. 1947. Ta 'lim al-muta 'allim-tariq al-ta 'allum (Instruction of the student: The method of learning) (translated by G.E. von Grunebaum and T.M. Abel). New York: King's Crown Press. https://doi.org/10.2307/2852960

Baba, S. and Zayed, T. 2015. Knowledge of shariah and knowledge to manage 'self' and 'system': Integration of Islamic epistemology with the knowledge and education. Journal of Islam, Law and Judiciary 1(1): 45-62.

Bakar, O. 2008. Tawhid and science, Islamic perspectives on religion and science (2nd ed.). Kuala Lumpur: Arah Publication.

Barbour, I.G. 2000. When science meets religion. San Francisco: Harper.

Bensaid, B. and Machouche S. 2017. Memorizing the words of God: Special reference to 'Abdul Rahman Ibn Khaldun (d. 1406 AD). Religious Education 112(4): 339-350. https://doi.org/10.1080/00344087.2016.1224001

Bīrūnī, Abu Rayhan. 1954. Al-qanun al-mas 'udi (vol. 1, pp. 1, 5). India: Da'irat al-Ma'arif al-'Uthmaniya,

Bukhari Abu Abdullah M. Ibn Isma'il. 1997. Sahih al-Bukhari (translated by M. Muhsin Khan) (vol. 1, Book 1: Revelation, hadith no. 1: 45). Riyadh: Darussalam.

Chopra, D. and Mlodinow, L. 2011. War of the worldviews: Science vs. spirituality. New York: Harmony Books. 
Cox, H. 2013. The secular city: Secularization and urbanization in a theological perspective. London: Princeton University Press. https://doi.org/10.23943/ princeton/9780691158853.001.0001

Dallal, A. 2007. Tolerance or compatibility? The search for a Qur'anic paradigm of science. United Kingdom: Foundation for Science Technology and Civilization Limited.

2010. Islam, science, and the challenge of history. New Haven and London: Yale University Press.

De Souza, M. 2008. Education for transformation: Meeting students' needs in changing contemporary contexts. International Journal of Children's Spirituality 13(1): 2737. https://doi.org/10.1080/13644360701834817

Elkins, D.N., Hedstrom, J.L., Hughes, L.L., Leaf, J.A. and Saunders, C. 1988. Toward a humanistic-phenomenological spirituality: Definition, description and measurement. Journal of Humanistic Psychology 28(4): 5-18. https://doi. org/10.1177/0022167888284002

Esposito, J.L. (ed.). 2009. The Oxford encyclopaedia of the Islamic world (vol. 5, p. 84). Oxford, US: Oxford University Press.

Gauch, Jr., H. 2009. Science, worldviews, and education. In Science, worldviews and education, ed. M.R. Matthews, 27-48. Dordrecht: Springer. https://doi. org/10.1007/978-90-481-2779-5 2

Giacalone, R. A. and Jurkiewicz C. 2003. Towards a science of workplace spirituality. In A Handbook of workplace spirituality and organization performance, eds. R.A. Giacalone and C.L. Jurkiewicz, 3-28. Armonk, NY: M.E. Sharpe. https://doi. org/10.4324/9781315703817

Gregory, N.D. 1999. What is science and how it works. United Kingdom: Princeton University Press.

Guessoum, N. 2010. Science, religion, and the quest for knowledge and truth: An Islamic perspective. Cultural Studies of Science Education 5: 55-69.

2011. Islam's quantum question: Reconciling Muslim tradition and modern science. New York: I.B. Tauris and Co. Ltd. https://doi.org/10.1007/s11422-0099208-3

Hassan, M.K. 2010. A return to the Qur'anic paradigm of development and integrated knowledge: The Ulu al-Albab model. Intellectual Discourse 18(2): 183-210.

Hoodbhoy, P. 1991. Islam and science: Religious orthodoxy and the battle for rationality. London: Zed Books Ltd.

Huff, T. 2003. The rise of early modern science: Islam, China and the West (2nd ed.). Cambridge, UK: Cambridge University Press.

Husain, S.S. and Ashraf, S.A. 1979. Crisis in Muslim education. Jeddah: King Abdulaziz University.

Ibn Ashur, Muhammad al-Tahir. 2006. Treatise on maqasid al-shari'ah (translated by Muhammad el-Tahir el-Mesawi). Virginia, USA: International Institute of Islamic Thought. https://doi.org/10.2307/j.ctvkc673b.4

Iqbal, M. 2009. The making of Islamic science. Kuala Lumpur: Islamic Trust Book. 
Jurjani, Ali Muhammad Sayed al-Sharif. 2004. Mu 'jam al-ta 'rifat. Cairo: Dar al Fadilah. Jurkiewicz, C.L. and Giacalone, R.A. 2004. A values framework for measuring the impact of workplace spirituality on organizational performance. Journal of Business Ethics 49: 129-142. https://doi.org/10.1023/b:busi.0000015843.22195.b9

Kamali, M.H. 2006. Reading the sign: A Qur'anic perspective of thinking. Islam \& Science 4(2): 141-164.

Kuhn, T.S. 1996. The structure of scientific revolutions (3rd ed.). Chicago, IL: The University of Chicago Press.

Lane, E.W. 1968. An Arabic-English lexicon (vol. 7, pp. 2502-2504). Beirut: Librairie du Liban.

Lantieri, L. 2001. A vision of schools with spirit. In Schools with spirit: Nurturing the inner lives of children and teachers, ed. L. Lantieri, 7. Boston: Beacon Press.

Miller, J.P., Karsten, S., Denton D., Orr, D. and Kates, I.C. 2005. Holistic learning and spirituality in education. Albany, NY: State University of New York Press.

Moore, M. 2005. Educating for the soul. In Holistic learning and spirituality in education, eds. J.P. Miller, S. Karsten, D. Denton, D. Orr and I.C. Kates, 9. Albany, NY: State University of New York Press.

Nasr, S.H. 2006. Spirituality and science convergence or divergence? In The essential Sophia: Love and wisdom, eds. S.H. Nasr and K. O'Brien. Bloomington, IN: World Wisdom Books.

Nawawi Yahya Abu Zakarya. 1987. Adab al-'alim wal muta'alim. Tanta: Maktabat al-Sahabah.

Taskın, Ö. 2014. An exploratory examination of Islamic values in science education: Islamization of science teaching and learning via constructivism. Cultural Studies of Science Education 9(4): 855-875. https://doi.org/10.1007/s11422-013-9553-0

Rahawi, Ishaq Ibn Ali. 1992. Adab al-tabib. Iran: Mu'assassat Mutala'at Tarikh.

Rāzi, Fakhr al-Din. 1981. Mafatih al-ghayb. Cairo: Dar al-Fikr.

Rosenthal, F. 2007. Knowledge triumphant: The concept of knowledge in medieval Islam. Leiden: Brill.

Samaian A.L. 2011. Reason and spirit in al-Bīrūnī’s philosophy of Mathematics. In Reason, spirit and the sacral in the new enlightenment: Islamic metaphysics revived and recent phenomenology of life, ed. A.T. Tymieniecka, 137-146. Netherlands: Springer. https://doi.org/10.1007/978-90-481-9612-8_9

Sardar, Z. 2006. How do we know? Reading Ziauddin Sardar on Islam, science and cultural relations. London: Pluto Press.

Sloan, D. 2005. Education and the modern assault on being human: Nurturing body, soul, and spirit. In Holistic learning and spirituality in education, eds. J.P. Miller, S. Karsten, D. Denton, D. Orr and I.C. Kates, 27. Albany, NY: State University of New York Press.

Solihu, A.K.H. 2014. Valuing biodiversity: A Qur'anic account. International Journal of Environmental Science and Development 5(3): 244-250. https://doi.org/10.7763/ ijesd.2014.v5.486

Speck, B.W. 2007. Spirituality in higher education: A literature review. In Searching for spirituality in higher education, eds. B.W. Speck and S.L. Hoppe, 16. New York: Peter Lang Publishing, Inc. 
Swinton, J. 2001. Spirituality and mental health care: Rediscovering a 'forgotten' dimension. United Kingdom: Jessica Kingsley Publishers.

Tahānawī, M. Ali. 1996. Kashshaf istilahat al-funun wal-'ulum (vol. 1, pp. 127-128, 1182). Beirut: Maktbat Lubnan.

Unal, A. 2010. The Qur'an with annotated interpretation in modern English. New Jersey: Tughra Books.

Watson, J. 2009. Science, spirituality and truth: Acknowledging difference for spiritual dialogue and human well-being. International Journal of Children's Spirituality 14(4): 313-322. https://doi.org/10.1080/13644360903293531

Wright, A. 2000. Spirituality and education. London: Routledge Falmer. 